\title{
Physiology of Fruit Set and Development in Apple under Temperate conditions: A Review
}

\author{
G. I. Hassan ${ }^{1}$, Ab. W. Wani ${ }^{1}$, S. Q. Dar ${ }^{1}$, M. Younus Wani ${ }^{3 *}$, \\ J. A. Sofi' ${ }^{2}$, T. R. Baba ${ }^{1}$, E. Parray ${ }^{1}$ and A. Rasool $^{1}$ \\ ${ }^{1}$ Division of Fruit Science, ${ }^{2}$ Division of Soil Science, ${ }^{3}$ College of Temperate Sericulture, \\ Mirgund, SKUAST-Kashmir, Shalimar, Srinagar, J\&K, India \\ *Corresponding author
}

\begin{tabular}{|l|}
\hline Ke y w o r d s \\
$\begin{array}{l}\text { Plant species, Seed } \\
\text { dispersal, Cell } \\
\text { division, auxin }\end{array}$ \\
\hline Article Info \\
\hline $\begin{array}{l}\text { Accepted: } \\
\text { 15 May 2020 } \\
\text { Available Online: } \\
\text { 10 June } 2020\end{array}$ \\
\hline
\end{tabular}

\begin{abstract}
A B S T R A C T
Plant species that bear fruits often utilize expansion of ovary (carpel) or accessory tissue as a vehicle for seed dispersal. Once the seed (s) mature, the tissue (s) of the fruit follow habitual progression of cell division and cell expansion, promoting growth of the fruit. As with many developmental processes in plants, plant hormones play important role in the synchronization of signals between the developing seed and its surrounding fruit tissue(s) regulating each phase of fruit development. Following pollination, fruit set is achieved through a de-repression of growth and an activation of cell division via the action of auxin and/or cytokinin and/or gibberellin .Following fruit set, growth of the fruit is facilitated through a relatively poorly studied period of cell expansion and endore duplication that is likely regulated by similar hormones as in fruit set (McAtetee et al., 2013). Pollination is an essential process for fruit set, fruit growth, fruit quality, and seed set of temperate fruits mostly apple cultivars. Being a temperate the various reasons for poor fruit set in the higher belts includes low temperature (coldness, rains) during flowering resulting in low bee activity (Verma and Jindal., 1985). The productivity of apple is obviously quite low and therefore, there is enough scope for its improvement. Low productivity (10-12 MT/ha) of apple in the state of $J \& K$ can be attributed to various factors like lack of pollinizers and pollinators, non-judicious use of pesticides and fertilizers, faulty pruning and training and climatic adversities particularly low temperature and rainfall during developmental stages of flowering, pollination, fertilization and fruit setting (Verma and Jindal, 1985).Different means can be employed for fruit set, productivity and quality improvement in temperate fruits like proper pollination ratio particularly pollenizers with flower synchronization with main cultivars, pollinators, use of hormones, nutrients or both. Under adverse climatic condition fruit set can be increased by use of plant growth regulators like auxins, cytokinins and gibberellins and some micronutrients, especially the calcium, boron (Lee et al., 2009) increases fruit set especially in apple.
\end{abstract}

\section{Introduction}

The valley of the Kashmir, situated in the midst of the Himalayan range of mountains roughly between $33^{\circ}, 01$ and $35^{\circ}, 00 \mathrm{~N}$ and $73^{\circ}, 48$ and $75^{\circ}, 30 \mathrm{E}$ has been famous for apple. The area under apple cultivation in $\mathrm{J} \& \mathrm{~K}$ is 160865 hectares with a production of 1647687 metric tons. The leading districts in the state of J\&K are Baramulla, Shopian,
Anantnag and Kulgam with a productivity of about 20.70, 10.13, 8.84 and 8.39 MT/ha respectively (Anonymous, 2018). Being a temperate the various reasons for poor fruit, set in the higher belts particularly in district Shopian, Kulgam and higher areas of Budgam district like Khag, Arizal etc includes low temperature (coldness, rains) during flowering resulting in low bee activity (Verma and Jindal., 1985). 
The productivity of apple is obviously quite low and therefore, there is enough scope for its improvement. Low productivity (10-12 $\mathrm{MT} / \mathrm{ha}$ ) of apple in the state of J\&K can be attributed to various factors like lack of pollinizers and pollinators, non-judicious use of pesticides and fertilizers, faulty pruning and training and climatic adversities particularly low temperature and rainfall during developmental stages of flowering, pollination, fertilization and fruit setting (Verma and Jindal, 1985).Different means can be employed for fruit set, productivity and quality improvement in temperate fruits like proper pollination ratio particularly pollenizers with flower synchronization with main cultivars, pollinators, use of hormones, nutrients or both.

Fruit set is the first step in fruit development, production and productivity; it is established during and soon after fertilization. Seed bearing plants have a unique double fertilization event with two pollen nuclei fertilizing the embryo and the endosperm (Dumas et al., 1998; Raghavan, 2003; Hamamura et al., 2012).

\section{Factors influencing fruit set}

Pollination is an essential prerequisite for the production of many fruit and seed crops, including apple. In apple, successful fertilization requires pollen transfer to the stigma, pollen germination, and successful pollen tube growth resulting in fruit set (Khalil and Hirst, 2017).The first step of successful apple pollination is the transfer of pollen to the stigmatic surface (typically vectored by bees) followed by an adhesion of pollen grains to the papilla cells of the stigmatic surface (Dresselhaus and FranklinTong, 2013). The deposited pollen hydrates and germinates and then pollen tubes penetrate the stigma and grow down the style. Pollen recognition occurs both on the stigmatic surface and within the style (Dresselhaus and Franklin- Tong, 2013). Once pollen reaches the base of the style, one sperm nucleus enters the egg cell to produce the embryo (resulting in seed set), and the other fuses with the two polar nuclei to produce the endosperm. Pollen source and temperature have a tremendous influence on the rate of pollen tube growth. Jackson (2003) proposed that the proportion of the stigmatic surface covered by the germinated pollen of apples and pears depends on the pollen donor and environmental temperature at the time of pollination. They reported that 'Spartan' pollen had a higher germination percentage than that of 'Cox's Orange Pippin' at 8 to $10^{0}$ $\mathrm{C}$ and 'Idared' at 14 to $16^{\circ} \mathrm{c}$. Linear correlations between pollen germination on the stigmatic surface and temperature were reported from 13 to $29^{0} \mathrm{C}$ (Yoder et al., 2009) and from 6 to $33.5{ }^{\circ} \mathrm{C}$ (Jefferies and Brain, 1984).

The rate of pollen tube growth is positively correlated with increasing temperature and negatively correlated with ovule longevity, pollen grains germinate freely at $10^{\circ} \mathrm{C}$ above and the process is practically inhibited at $4.4^{\circ} \mathrm{C}$ or lower temperature and reduction of effective pollination period occurs at lower temperature shown in Fig 1(Gold way et al., 2012).Images of pistils were acquired using a 10. 0.45 NA objective and Nikon DS-Ri1 color camera on a Nikon 90i epi-fluorescence microscope using blue (350/50 460/50) and red (560/40 630/60) filter sets. Individual images of each pistil were manually assembled into a montage (fig-2).

Almost all apple cultivars are reported to be either self-incompatible or semi-compatible and require cross-pollination to set fruit in marketable quantities (Garratt et al., 2014). For commercial production, at least two cross-compatible cultivars with synchronous flowering are recommended mentioned in 
table 1 and 2 (Banday and Sharma, 2010). There is significant decline in fruit set with increasing distance between pollinizer and main cultivars, and pollinizers should be planted at proper ratio i.e. $11 \%, 15 \%, 25 \%$ and $33 \%$ for effective pollination (Pandith, 2014). Pollen source is considered to be one of the most influential factors affecting the fruit set. Pollen density on the stigmatic surface is positively correlated with pollen tube growth and fruit growth rate (Zhang et al., 2010).

\section{Plant growth regulators}

Fruit set has traditionally been attributed to the action of three hormones, auxin, and/or gibberellin, and/or cytokinin $\left(\mathrm{GA}_{3}\right.$ and $\mathrm{CPPU})$, nutrients ( $\mathrm{Ca}$, Boron, $\mathrm{K}$ and $\mathrm{N}$ ) alone or in combination (Mariotti et al., 2011 and Wani et al., 2017). Plant hormones (also known as phytohormones) are naturally occurring organic substance that influence growth and development in very low concentrations and whose action may beinvolved in places remote from their origin. Hormones determine the formation of flowers,stems, leaves, the shedding of leaves and the development and ripening of fruit. Plants, unlike animals, lack glands that produce and secrete hormones; instead each cell is capable of producing hormones. Hormones are vital to plant growth and lacking them, plants would be mostly a mass of undifferentiated cells (Jain, 2013). Plant Growth Regulators (PGR), on the other hand, include naturally occurring plant growth substances also called phytohormones, as well as synthetic compounds among which are chemicalanalogs, materials that alter hormone levels (hormone-releasing agents or synthesis inhibitors) and materials that alter hormone sensitivity (Hajam et al., 2017) . There are mainly five well-established categories of "classical" phytohormones, grouped together based on their structural similarities and on their effects on plant physiology. These five hormones include auxins, gibberellins, cytokinins, ethylene and abscisic acid. The other PGRs such as oligosaccharins, brassinosteroids, salicylic acid, jasmonates, polyamines, nitric oxide (NO), strigolactones, karrikins etc have been found recently. Their exogenous applications have shown the tremendous effect on fruit crops. In general plant hormones have major two effects and grouped accordingly as (1) Plant growth promoters:- substances which improve the overall health, growth and development of plants and (2) Growth retardants:- the group of chemicals which have common physiological effect of reducing stem growth by inhibiting cell division of sub apical meristem. The influences on fruit production by the growth regulators are numerous and are employed in a wide range of circumstances varying from tissue culturally propagated plants to enhancing post-harvest storage life through almost all stages of plant life in between. It is not always the effect of single growth regulator but the interaction effect of different hormones in combination for instance; the ratio of cytokinin to auxin determines the fate of callus if it is high it promotes shoot proliferation while as low cytokinin: auxin ratio enhances root formation (Jain, 2013).Application of these hormones alone can trigger fruit development to a certain extent and, in many plant species, application in combination will induce normal fruit growth even in the absence of fertilization i.e parthenocarpy (Gillaspy et al., 1993; Vivian-Smith and Koltunow, 1999), indicating that an interplay between these hormones is necessary for fruit set and fruit growth. In many species, auxin and cytokinin levels in the seed increase during seed formation (Yang et al., 2002).Naturally occurring phytohormones, their chemical analogs, hormone-releasing agents, hormone sensitivity altering agents and hormone synthesis inhibitors collectively form plant 
growth regulators (Hajam et al., 2017). In order to increase the yield of monoecious crops, the increase female flowers are prerequisite for the same, Ethrel (250-1000 ppm) and CPPU (20-80 ppm) sprays work to induce female and intersexual flowers in male plants of papaya (Kumar, 1998). Fruit quality fulfillment comes to be a paramount concern of the researchers and fruit grower's important goal, particularly regarding optimizing size, increasing firmness, TSS and protection against russeting, sunburn and other physiological disorders. Foliar sprays of PGRs $\left(\mathrm{GA}_{3}\right.$ at $20-40 \mathrm{ppm}$ or NAA at $25-50$ ppm) enhanced apple yield and fruit quality traits (Osama et al., 2015). GA 3 increase fruit size, improves fruit firmness, increases vitamin-C, TSS, total sugars, sweetness index and overall sensory ratings of 'Red Delicious' apples (Hajam, 2017). Gibberellic acid and salicylic acid are also reported to increase yield, fruit acidity, reducing sugars, TSS, TSS/ acid ratio, fruit firmness and fruit chlorophyll $\mathrm{a}$ and $\mathrm{b}$ content peach trees (ElShazly, 2013). Ethylene serves as a key ripening hormone of climacteric fruits and can influence ripening in many nonclimacteric fruits (Giovannoni et al., 2010). Treatment with high concentrations of ethylene stimulates respiration and increases the levels of fatty acids (FA) and volatiles and at the same time decreases firmness (Banday, 2006; Harb et al., 2008). The combined spray of NAA $10 \mathrm{ppm}$ and ethephon $150 \mathrm{ppm}$ at full bloom can reduce fruit set up to $34 \%$ in apple (Banday, 2006).

\section{Impact of GA and cytokinin on fruit set}

Gibberellins are closely related with parthenocarpy in apples: application of gibberellins and the combination of gibberellins with cytokinins can induce parthenocarpic fruiting. Exogenous plant hormone application to unfertilized ovaries might serve as a switch that starts the continuing autonomous development of the fruit and controls the continuity of the flow of assimilates and nutrients required for fruit growth (Bangerth and Schroder, 1994). Gibberellic acid, Auxin(NAA) and cytokinin or in combination enhances fruit set in temperate fruit crops especially apple, pear and cherry during bloom $(50 \%)$ by compensating the poor pollination due to the unfavourable weather conditions even in the absence of fertilization i.e parthenocarpy (Wani et al., 2017 and Mariotti et al., 2011 ) shown in table $3 \& 4 . \mathrm{GA}_{3}$ at $250-500 \mathrm{mgL}^{-}$ ${ }^{1}$ during flowering gave a good (20-40 per cent) fruit set in sour cherries (Parnia and Burlani1986). Gibberellic acid intensifies an organ ability to function as a nutrient sink. It also increases the biosynthesis of IAA in plant tissues, delays the formation of separation layer, and thus enhances fruit retention (Wally et al., 1999 and Wani et al., 2017). Cytokinin as CPPU has a promoting effect on fruit set and reducing $\mathrm{ABA}$ content, due to the physiological basis of CPPU on fruit setting and fruit retention (Guirguis et al., 2003 and Wani et al., 2017). The increase in fruit size could be attributed directly to the CPPU effects whereas; exogenous application of CPPU acts as early and rapid on cell division in the fruitlet and also on subsequent growth. Thus, the fruit becomes bigger in size due to the increased cells, which are able to attract so much water, minerals and carbohydrates that enable the fruit to expand to large size (Kano, 2003).

In "Cox Orange" apple trees application of exogenous hormones $\mathrm{GA}_{3}$, diphenylurea (CPPU) at full bloom improved fruit set by improving the number of the pollen tubes that actually reach the ovaries of the flowers (Williams and Flook, 2012). Sotomayor et al., (2012) revealed the influence of the different growth regulators like gibberellic acid, promalin, naphathaleneacetic acid (NAA), thidiazuron, kinetin, point-tomatomone and 
brassinolide on the fruit set of almonds on the branches at 50 days after anthesis and reported that promalin achieved increased fruit set.

\section{Impact of nutrients on fruit set}

Nutrients play an important role in fruit setting which in turn increases the yield, production and productivity of fruit crops especially apple, pear, cherry, peach etc. The most commonly used nutrients include calcium $(\mathrm{Ca})$, boron $(\mathrm{B})$, nitrogen $(\mathrm{N})$ etc. Nutrient deficiency of $\mathrm{Ca}$ and $\mathrm{B}$ particularly at flowering and fruit development stage causes severe pollination problems, poor fruit set, low productivity and inferior fruit quality that ultimately gets reflected by striking drop in economic wellbeing of farmers. Nutrient management plays an important role in fruit production and fruit quality as nutrients are essential for plant life and a plant deprived of any one of these elements would cease to exist (Marschner, 1995). Calcium and boron are among the essential nutrients, found deficit in most of the soils. Generally, B deficiency in plant is observed on coarse textured soils (Shorrocks, 1997) due to intensive leaching of this nutrient from top soil layers (Gupta, 1979). On the other hand, $\mathrm{Ca}$ is considered to be deficit in highest rainfall areas and is less mobile in soils (Zatylnyl and St-pierre, 2006).

The importance of $\mathrm{B}$, as one of the essential nutrient is its role in growth, flowering, fruit set and yield has been well documented by scientists all over the world (Stampar et al., 1999 and Stampar et al., 2000). Likewise, Ca is essential for plant growth, cell division, membrane stability, cell elongation and turgidity (Saure, 2005). Calcium promotes the root and fruit growth and quality of fruit (Kadir, 2004). Knowing that nutrients required for fruit growth and development is only one aspect of successful fruit production, but simultaneously optimum yield also requires knowing the rate to apply, the method and time of application, the source of nutrients to use, and how the elements are influenced by soil and climatic conditions (Tucker et al., 1999).Boron is an essential micronutrient in plants that is often deficient in most soils because most of the boron in the soil is adsorbed to clay minerals, hydrous metal oxides, and organic matter in soils. In addition, boron can be co-precipitated with calcium carbonate making it unavailable to the roots. Once inside the plant, B moves along with transpiration stream and uptake is increased with increasing temperature. Boron deficiency symptoms are often seen in actively growing tissues indicating that $\mathrm{B}$ is a highly immobile element because it forms complexes with cell wall constituents. In most plant species, foliar applied B is rather immobile. The major role of $\mathrm{B}$ in fruit trees involves fruit set. Boron is important nutrient for fruit setting which helps in pollen germination and pollen tube growth, which is likely to increase fruit set, yield and quality (Ganie et al., 2013 and Wojcik and Wojcik, 2006). Apple, pear and cherry flowers are very high in $B$. If the $B$ content is deficient, the flowers die result in poor fruit set. The B needed in the flower is transported mainly from the reserves in the adjacent branches and not from the roots during flower development. Close attention to $\mathrm{B}$ levels is important because both low and high concentrations cause poor fruit quality. Boron is the key nutrient for flowering, fruiting and internal and external fruit quality. It is involved in sugar transport, lignifications, RNA metabolism, respiration, indole acetic acid (IAA) metabolism, cell wall synthesis and carbohydrate metabolism (Jeremy, 2007). Verma and Jindal ,(1985) studied that in apple rate of pollen tube growth is positively correlated with increasing temperature and negatively correlated with ovule longevity, pollen grains germinate freely at $10^{\circ} \mathrm{C}$ above 
and the process is practically inhibited at $4.4^{\circ} \mathrm{C}$ or lower temperature and reduction of effective pollination period occurs at lower temperature with results in poor fruit set. Yasser et al., 2013 studied the effects of some of nutritional materials on fruit set and its characteristics in apple and reported that different treatment had various effects on fruit set and fruit quantity and quality in way that treatments contain boron and zinc compound had the most effect on fruit set than other treatments and untreated control.

Wojcik and Wojick (2006) observed that prebloom foliar application of boron to apple trees increases fruit set $25.3 \%$ as compared to untreated control 11.4\%.Avocado pollen germination, pollen tube growth and fertilisation of the ovule have all been shown to be enhanced following application of foliar boron to flowers (Jaganath and Lovatt, 1995). Foliar applied boron in the form disodium octaborate tetrahydrate (commercially available as Solubor) to mature 'Hass' avocado leaves and flowers significantly increased boron content in inflorescences and was correlated with an increase in fruit set (Robbertse et al., 1992).

Like boron, calcium is also an important nutrient in plant nutrition. Where it is abundant in the soil, calcium is abundant in leaves, since it is taken up passively by growing roots (not requiring an energy source). Apparently, only the region just behind the tips of a growing root is capable of calcium uptake (unlike $\mathrm{K}$ and $\mathrm{P}$ ), so factors inhibiting root growth also inhibit its uptake.

Calcium moves almost exclusively in the xylem with very small concentrations being found in the phloem. Therefore, once in an organ (such as a mature leaf), calcium is not readily transported out, even during senescence. Fruit calcium levels are low, since nutrients in fruit tissues are supplied mostly by the phloem. For this reason, fruit and leaf calcium levels are poorly correlated; meaning leaf samples cannot be used to determine the fruit's calcium status. Calcium a relatively large divalent cation has numerous functions in the plant cell.

Most of the functions of calcium as a structural component of macro-molecules are related to its capacity for co-ordination by which it provides stable but reversible intermolecular linkages, predominantly in the cell wall at the plasma membrane. Calcium acts as a secondary messenger in the signal conduction between environmental factors and plant response in terms of growth and development (Marschner, 1995).

Although soil application is the most common method of fertilizer application to the fruit trees; however, for quick response, foliar nutrient applications are preferred. Foliar application also entails efficient and economic use of fertilizers; besides, minimising ground water pollution. Further, plants sometime grow at rates that are faster than the ability of the roots to absorb and translocate minerals to the critical leaf, flower and fruit tissues, foliar sprays can often help to overcome deficiency and maintain optimum nutrient levels of those critical tissues. There are different sources of both boron and calcium for foliar sprays. Calcium can be applied through calcium chloride, calcium nitrate, calcium hydroxide, chelated calcium etc. Likewise B can also be supplied through borax, boric acid, disodium octaborate tetra-hydrate (solubor) (Wojcik and Wojcik, 2006).

\section{Fruit development}

Fruit goes through a complex developmental sequence over a growing season. Understanding the processes involved, what supports fruit growth and what limits it, helps to support good crop management. 
Physiologically and biochemically fruit development can be divided into four phases:

\section{Phase-I: Fruit set}

It includes ovary development in the flower, a decision to abort or proceed with further development. Growing pollen produces gibberelic acid and application of gibberlins induce parthenocarpic fruit, therefore it is believed that gibberlin is triggering signal. Thereafter there is as increased wave of auxin production by the style and then the ovary. Continued fruit development usually relies on continued presence of developing seed. Seed abortion or removal causes fruit abortion, which can be reversed by auxin application.

\section{Phase-II}

This phase involves a period of most rapid cell division. This phase is controlled by developing seed. The number of fertilized ovules in a fruit is correlated with both the initial cell division and the final size of the fruit.

\section{Phase-III}

It is the period of most rapid growth when cell division more or less cease, and growth is almost exclusively by cell enlargement. Early in the cell enlargement phase, vacuoles are formed in the cells and these increase in size as the cells enlarge ultimately occupying most of the space in the centre of the cell. In this phase, food reserves are accumulated and most fruits attain their final shape and size before the onset of ripening.

\section{Phase-IV}

Ripening phase. It involves softening, increased juciness and sweetness and colour changes in the fruit.

\section{Fruit growth pattern}

Fruits undergo different developmental stages. A rapid increase of fruit volume after fruit set is usually followed by a period of slower growth. Towards the end of fruit ripening, fruit volume and weight increase again at a faster rate (Lasko and Goffinet, 2013). This sigmoid growth pattern can be explained as follows: The first stage is a period of rapid cell division with a fast increase in the total number of cells. The "lag" phase which follows is represented by internal structural changes such as the hardening of the stone (i.e. the fruit endocarp) in cherries, plums and peaches, or the ripening of embryos in pome fruits. At the next stage, a cell elongation phase associated with a rapid incorporation of water, fruits appear to grow faster (Aichner et al., 2001) [2]. The final fruit size potential, and generally the actual size at harvest, depends primarily on the number of cells in the fruit. And since cell numbers are set in only the first few weeks after bloom, that is a critical time for the whole season. Fruit with low cell numbers from excess competition after bloom, due to late or inadequate thinning, can never catch up later to become large fruit. Thus we can say fruit grows mainly by:

Cell Division sets potential for ultimate size of fruit.

Cell Expansion achieves mature size.

\section{Fruit growth curve}

Apple has a typical S-shaped curve. The growth curve of pear is similar to apple except that it doesn't show the slow growth period at the end (because pears are picked green-mature). Peach and other stone fruits (also fig, currant, pistachio, and seeded grapes) show double sigmoid curve because of a period of slow growth during pit hardening (Figure 4). During pit hardening 
both flesh and kernel tissues grow at reduced rates, while the stony endocarp increases rapidly in dry weight. The growth of the seed in length indicates that growth stops at the beginning of pit hardening. Yet growth as measured by dry weight shows that it continues to grow until harvest (M.Faust, 1995).

\section{Harmonal changes during the fruit development}

Apple seeds, during their development in the fruit, produce a sequence of different types of hormones, the appearance and disappearance of which is linked with successive stages in the development of the endosperm and embryo (Figure 5). The first stage of seed development, characterized by the development of a free nuclear endosperm but very little growth of the embryo, is particularly associated with the presence of cytokinins (Zwat et al., 1963). Cytokinen levels increase after pollination (Matsuo et $a l ., 2012$ ) and are generally considered to play a critical role in the stimulation of cell division during fruit development (Wismer et al., 1995; Srivastava and Handa, 2005). This stage is terminated 4 to 5 weeks after full bloom by the development of the cellular primary endosperm and the appearance in the seed of two indole auxins (Luckwill, 1957) identified as 3-indoleacetylaspartic acid and ethyl-3- indole acetate (Raussendorf Bargen, 1962) . The second developmental stage is associated with the rapid growth of the embryo, the digestion of the nucellus and primary endosperm and the formation of a secondary endosperm which forms a tight sheath around the fully grown embryo. Luckwill (1969) confirmed the presence during this stage of gibberellins A4 and A7, which first appear 4 to 5 weeks after full bloom and quickly build up to a peak concentration at 9 weeks after bloom, at the time when the embryo has almost reached its final size. Cell expansion is regulated by auxin, gibberlin, and brassinosteroid(Pattison and Catala, 2012). Cell enlargement depends both on cell wall loosening and increase turgor pressure (Cosgrove, 2005) While auxin mostly controls cell division during fruit set, it is thought to play an important role during the growth phase by influencing cell enlargement together with gibberllins (Csukasi et al., 2011).

One of the main functions of the relatively high concentration of hormones found in developing seeds may be the mobilization of essential metabolites-particularly carbohydrates and soluble nitrogen-against the competing demands of the growing shoots. It is certainly true that fruits with no seeds or with only a low seed content are not normally able to survive this competition, though they can be made to develop if competing vegetative growth is suppressed (Abbott, 1960) . There is also rather strong circumstantial evidence that gibberellins translocated from the seeds to the bourse may inhibit flower initiation in the bourse bud, thus giving rise to the phenomenon of biennial blossoming (Luckwill, 1969).

\section{Parthenocarpic fruit set}

Bangerth and Schroder (1994) reported that the gibberellins are closely related with parthenocarpy in apples and also application of gibberellins in the combination with cytokinin induce parthenocarpy. Sadamatsu et al., (2004) reported that the application of gibberllic acid $\left(\mathrm{GA}_{3}\right)$ on loquat increased the parthenocarpic fruit set with concentrations 500 and 1000 ppm even under growth in cold stress and it was reported that $\mathrm{GA}_{3}$ is an important factor in inducing parthenocarpic fruit set in fruit crops.

Yahata et al., (2006) conducted an experiment with an objective to induce seedless fruit set 
and growth in the triploid loquat by applying $\mathrm{GA}_{3}, \mathrm{GA}_{4}, \mathrm{GA}_{7}$ or $\mathrm{GA}_{4+7}$ at $200 \mathrm{mg} \mathrm{L}^{-1}$ in combination with forchlorfenuron (CPPU) at $20 \mathrm{mg} \mathrm{L}^{-1}$ to flowers and fruitlets two times, at bloom and 57 days after bloom. The flowers were not emasculated. Treatment solutions of $100 \mu \mathrm{L}$ were applied to each flower and fruitlet. Untreated control fruit gradually abscised and final fruit set was $0 \%$. When $\mathrm{GA}_{3}, \mathrm{GA}_{4}, \quad \mathrm{GA}_{7}$ or $\mathrm{GA}_{4+7}$ in combinations with CPPU were applied, fruit sets at harvest were about $61 \%, 40 \%, 74 \%$ and $56 \%$, respectively. The harvested fruits were all seedless. These results suggest that $\mathrm{GA}_{3}+\mathrm{CPPU}$ is more effective than other combinations of GA+CPPU for seedless fruit production in the triploid loquat without decreasing the fruit quality.

McCartney and Wargo (2008) studied that the Promalin (6-BA+ $\left.\mathrm{GA}_{4+7}\right)$ increases cropping of apples even after a freeze by promoting Parthenocarpic fruit set as compared to untreated control. Watanable et al., (2008 a) revealed that Gibberellins $\left(\mathrm{GA}_{4+7}\right) @ 250$ and $500 \mathrm{ppm}$ can stimulate Parthenocarpic fruit development in apples during cold and freeze conditions as compared to untreated control. Watanable et al., (2008 b) studied the effects of plant growth regulators on fruit set and fruit shape of Parthenocarpic apple and found that in 'Ohrin', the application of $\mathrm{GA}_{3}$ and gibberellin $\mathrm{A}_{4+7}\left(\mathrm{GA}_{4+7}\right)$ showed a higher fruit retention rate before flowering than after and Parthenocarpic fruits were induced even when uniconazole (UCZ) was sprayed after flowering, but not before flowering. The calyx end was large in $\mathrm{GA}_{4+7}$ and in $\mathrm{GA}_{3}$ and CPPU singly, and $\mathrm{GA}_{3}$ and CPPU combined treatments, which increased the percentage of fruit set. These results suggest that gibberellins before flowering trigger Parthenocarpic apple. The use of gibberellins or complex of gibberellins and cytokinins (Promalin), stimulate parthenocarpy in pear as studied by Musacchi (2008).
Niu et al., (2014) reported the effect of exogenous application of $\mathrm{GA}_{4+7}$ and $\mathrm{N}-(2-$ chloro-4-pyridyl)-N-phenylurea on induced parthenocarpy in Pyrus pyrifolia "Cuiguan" and revealed that parthenocarpy largely depends on the coordination action of hormones produced in unpollinated ovaries, but can be induced by application of exogenous hormones like $\mathrm{GA}_{4+7}$ which induced the highest fruit set as compared to untreated control.

Application of phytohormones and nutrients alone or in combination produced significant effect with respect to Parthenocarpic fruit set. Parthenocarpic fruit set in an apple $c v$. Red Delicious, showed significant increase with increased concentration of $\mathrm{GA}_{3}$. It was observed that at lower concentration i.e., at $\mathrm{T}_{2}$ (GA3 @ 250 ppm) Parthenocarpic fruit set of $36.86 \%$ was recorded and with further increase in $\mathrm{GA}_{3}$ concentration Parthenocarpic fruit set was increased to $45.21 \%$ as in treatment $\mathrm{T}_{3}$ (GA3 @ 500 ppm) whileas lowest Parthenocarpic fruit set of $5.09 \%$ was recorded in control $\left(\mathrm{T}_{1}\right)$.

However, the highest (52.69\%) Parthenocarpic fruit set was recorded in combination treatment $\mathrm{GA}_{3} @ 500$ ppm+CPPU @ 5 ppm)]. Fig-1 indicates Parthenocarpic fruit set in an apple $c v$. Red Delicious, showed significant increase with increased concentration of $\mathrm{GA}_{3}$.

\section{Impact on seed number}

$\mathrm{GA}_{3}$ at $50 \mathrm{mg} / \mathrm{L}$ at full bloom and three months after first spray were most effective treatments in reducing fruit seed contents in guava and persimmon (Wally et al., 1999). Icka and Damo (2013) reported that the application of promalin @ 125 ppm reduces the seed number of Red Delicious and Golden Delicious 2.5 and 2.1 respectively as compared to untreated control 7.6 and 7.8. 


\section{Impact of PGRs on fruit drop and fruit retention}

Hossain (2015) in a study found that the application of $\mathrm{GA}_{3} @ 50$ ppm reduces fruit drop $8 \%$ compared to $20 \%$ untreated control. Prang et al., (1998) revealed a significant decrease in fruit drop in 'Starkrimson' apple trees with GA spray $(100 \mathrm{mg} / 1)$ or urea spray $(0.4 \%)$ during full or $50 \%$ bloom. Greene (1989) reported that the application of CPPU @ $100 \mathrm{mg} / \mathrm{l}$ during flowering time reduced fruit drop of 'Early McIntosh' by $47 \%$ compared with the control. He observed that fruits treated with CPPU were difficult to separate from the spur that was the reason for reduction of pre harvest fruit drop of 'Early McIntosh'.Wally et al., (1999) observed that $\mathrm{GA}_{3}$ at $50 \mathrm{mg} / \mathrm{L}$ at full bloom and three months after first spray were most effective treatments in reducing pre harvest fruit drop in guava and persimmon.

Davies and Zalman (2006) studied that the $\mathrm{GA}_{3}$ significantly increased the total number of fruits, the fruit weight per plant by reducing pre-harvest fruit drop in orange, control branches showed the highest number of fruit dropped (52\%), with the least percentage of fruit dropping observed (32\%) in $\mathrm{GA}_{3}$ at $20 \mathrm{mg} / \mathrm{L}$ treated branches followed by $\mathrm{GA}_{3}$ at 50 and $100 \mathrm{mg} / \mathrm{L}$ treatments.

Chao and Lovatt (2006) reported that the application of $\mathrm{GA}_{3}\left(150\right.$ or $\left.250 \mathrm{mg} \mathrm{L}^{-1}\right)$ at $60 \%$ and $90 \%$ full bloom, $75 \%$ petal fall and 10 days after $75 \%$ petal fall resulted in retention of significantly more fruits (kilograms and number per tree) compared to untreated control trees. Wally et al., (1999) studied that the application of $\mathrm{GA}_{3}$ and CPPU increases fruit set of apple and the best combination was $\mathrm{GA}_{3}$ at $200 \mathrm{ppm}+\mathrm{CPPU}$ at 5 ppm (86.28 and 85.86\%) through the two studied seasons respectively. They justified the role of $\mathrm{GA}_{3}$ stating that it intensifies an organ ability to function as a nutrient sink, it also increases the biosynthesis of IAA in plant tissues, delays the formation of separation layer (Wasfy, 1995), thus enhancing fruit retention.

\section{Impact on return bloom (bloom density)}

Bloom density $=$ No. of Flower buds $/ \mathrm{cm}^{2}$ BCSA

Where, branch cross sectional area $($ BCSA $)=$ Girth $^{2} / 4 \pi$

Return bloom $=\frac{\text { Previous bloom density-Current bloom density }}{\text { Previous year flowers }} \times 100$

Ramirez(2004) reported that the exogenous application of cytokinins to apple spurs at the time of fruit bud initiation increased return bloom in the following spring. Greene (1989) found that CPPU at 10 or $100 \mathrm{mg} \mathrm{liter}^{-1}$ and gibberellin acid or promalin (50or $300 \mathrm{mg}$ liter $^{-1}$ ) at full bloom reduced 'McIntosh' return bloom. Greene (1989) also reported that the return bloom of Spur Delicious apple after application of CPPU @ 5ppm at full bloom was recorded as 5.7 as compared to untreated control (12.0).

McCartney (1994) studied that the application of $\mathrm{GA}_{3} @ 330$ ppm applied at full bloom reduced the proportion of flowering spurs of 'Braebum' apples in the following year. $\mathrm{GA}_{3}$ at 100,500 , or $1000 \mathrm{mg} /$ liter was applied at the beginning of spring (at full bloom) and at the highest concentration, $\mathrm{GA}_{3}$ reduced flower bud formation in the following spring and produced the lowest yields (Maksymiuk et al., 1986).

Trees of Golden Delicious, King of the Pippin and Jonagold were treated with $\mathrm{GA}_{3}$ (200 $\mathrm{mg} /$ liter) applied at full bloom reduced flower induction in the following spring (Trompt, 1982). 
Table.1 Recommended varieties and pollinizers for apple in Jammu and Kashmir (Banday and Sharma, 2010)

\begin{tabular}{|c|c|c|}
\hline Time & Main & Pollinizers \\
\hline Early Season & $\begin{array}{l}\text { Irish Peach, Benoni, Early } \\
\text { Shanburry, Mollie’s Delicious, } \\
\text { and Early Red One. }\end{array}$ & $\begin{array}{l}\text { Tydeman's Early Worcester, } \\
\text { Summer Queen. }\end{array}$ \\
\hline Mid-Season & $\begin{array}{l}\text { Gala Mast, Cooper IV, } \\
\text { Oregon Spur, Vance Delicious, } \\
\text { Well spur, Red chief, Imperial } \\
\text { Gala, Red Fuji, Red Spur, } \\
\text { Firdous, Shireen and Top Red. }\end{array}$ & $\begin{array}{l}\text { Sparten, Red Gold, } \\
\text { Ginger Gold, McIntosh and } \\
\text { Lord Lambourne. }\end{array}$ \\
\hline Late Season & $\begin{array}{l}\text { Royal Delicious, Ambri, Rich- } \\
\text { a-Red, Lal Ambri, Red } \\
\text { Delicious and Akbar. }\end{array}$ & $\begin{array}{l}\text { Golden Spur, Granny Smith, } \\
\text { More Spur Gold, Sunhari, } \\
\text { Golden Delicious }\end{array}$ \\
\hline
\end{tabular}

Table.2 Recommended number of hives in different fruit crops

\begin{tabular}{|c|l|}
\hline Fruit crop & Number \\
\hline Almonds & $5-8$ hives $/$ ha. \\
\hline Apple & $3-5$ hives $/$ ha. \\
\hline Apricot & $2-3$ hives $/$ ha. \\
\hline Cherries & $2-3$ hives $/$ ha. \\
\hline Pear & $3-4$ hives $/$ ha. \\
\hline Peaches, plums and nectarines & $2-3$ hives $/$ ha. \\
\hline
\end{tabular}

Table.3 Impact of PGR's in Fruit Set

\begin{tabular}{|l|l|l|}
\hline Fruit Crop & Growth regulators & Response \\
\hline Apple & Paclobutrazol 1000ppm & Improve fruit set \\
\hline GA3+NAA & Increase initiation and final set & \\
\hline Daminozide @ 2000ppm & Increase flower buds & \\
\hline Ethephon & Decrease fruit set Increase size of fruit & \\
\hline Grapes & GA3 & $\begin{array}{l}\text { Increase fruit set causes berry } \\
\text { enlargement }\end{array}$ \\
\hline CCC@ $2000 \mathrm{mg} / \mathrm{l}$ & Increased fruit set Inhibited shoot growth & Improve fruit set and retention \\
\hline Mango & Paclobutrazol & \\
\hline $\begin{array}{l}\text { CPPU }(10 \mathrm{ppm}) 14 \text { days after } \\
\text { bloom }\end{array}$ & Increase fruit retention, yield and quality & \\
\hline Citrus & GA3 & Increase fruit retention \\
\hline $\begin{array}{l}2,4-D @ 10 p p m \\
\text { Paclobutrazol @ 2.5g/L }\end{array}$ & Increase fruit retention & \\
\hline Pear & Increase fruit set & $\begin{array}{l}\text { Increase fruit set and } \\
\text { retention, Parthenocarpy }\end{array}$ \\
\hline Chlormiquat@ 500ppm & GA3@50ppm & \\
\hline Peach & Role in flowering \& fruit set & Improved fruit set in Le Conte \\
\hline Alar $@ 500 \mathrm{ppm}$ & CCC $1000 \mathrm{ppm}$ & \\
\hline & Increase fruit set and fruit size & \\
\hline
\end{tabular}


Table.4 Effect of Pro-hexadione calcium and Thidiazuron on fruit set in Royal Gala/M9 (Rootstock)

\begin{tabular}{|l|c|c|c|}
\hline Treatment & Fruit set \% & $\begin{array}{l}\text { Number of } \\
\text { Fruits/tree }\end{array}$ & Yield(kg/tree) \\
\hline Control & 50.75 & 332.83 & 32.75 \\
\hline TDZ $(10 \mathrm{mg} / \mathrm{L})$ & 70.95 & 361.33 & 38.97 \\
\hline P-Ca $(55 \mathrm{mg} / \mathrm{L})$ & 62.38 & 430.50 & 48.40 \\
\hline TDZ + P-Ca & 96.88 & 606.50 & 62.6 \\
\hline
\end{tabular}

Table.5 Duration of cell division in fleshy fruits (Westwood, 1967)

\begin{tabular}{|l|l|}
\hline Apple & 4-5 Weeks \\
\hline Pear & 7-9 Weeks \\
\hline Peach & 4 Weeks \\
\hline Plum & 4 Weeks \\
\hline Sour Cherry & 10 Days \\
\hline Avacado and Strawberry & Until Harvest \\
\hline
\end{tabular}

Table.6 Effect of PGRs and Nutrients on fruit set, Parthenocarpic, non-Parthenocarpic, seed number, fruit retention, fruit drop and return bloom (Wani et al., 2017)

\begin{tabular}{|c|c|c|c|c|c|c|c|}
\hline Treatments & $\begin{array}{l}\text { Fruit } \\
\text { set } \\
(\%)\end{array}$ & $\begin{array}{l}\text { Partheno- } \\
\text { carpic } \\
\text { fruit set } \\
(\%)\end{array}$ & $\begin{array}{c}\text { Non- } \\
\text { partheno- } \\
\text { carpic fruit } \\
\text { set }(\%)\end{array}$ & $\begin{array}{c}\text { Seed } \\
\text { number } \\
\text { per } \\
\text { fruit }\end{array}$ & $\begin{array}{c}\text { Fruit } \\
\text { retention } \\
(\%)\end{array}$ & $\begin{array}{c}\text { Fruit } \\
\text { drop } \\
(\%)\end{array}$ & $\begin{array}{c}\text { Return } \\
\text { bloom } \\
(\%)\end{array}$ \\
\hline Control & 23.08 & 5.09 & 7.1 & 46.43 & 53.57 & 46.43 & 12.9 \\
\hline GA $3 @ 250$ pm & 53.88 & 36.86 & 2.4 & 47.34 & 52.66 & 47.34 & 9.02 \\
\hline $\mathbf{G A}_{3} @ 500$ ppm & 62.91 & 45.21 & 1.6 & 52.32 & 47.68 & 52.32 & 7.32 \\
\hline Solubor@0.15 \% & 32.29 & 10.36 & 21.94 & 45.49 & 54.47 & 45.49 & 16.48 \\
\hline $\begin{array}{c}\text { Nutrient mixture } \\
\text { @2ml/L }\end{array}$ & 35.91 & 11.29 & 24.11 & 45.31 & 54.68 & 45.31 & 16.73 \\
\hline CPPU @ 5 ppm & 42.25 & 20.27 & 21.67 & 44.95 & 55.05 & 44.95 & 6.41 \\
\hline $\begin{array}{c}\mathbf{G A}_{3} @ 125 \text { ppm + } \\
\text { CPPU @ } 5 \text { ppm }\end{array}$ & 52.05 & 30.09 & 21.94 & 44.16 & 55.84 & 44.16 & 8.69 \\
\hline $\begin{array}{c}\mathbf{G A}_{3} @ 250 \\
\text { ppmCPPU @ } 5\end{array}$ & 56.51 & 35.71 & 20.11 & 44.52 & 55.48 & 44.52 & 6.21 \\
\hline $\begin{array}{c}\text { GA } 3 \text { 500ppm + } \\
\text { CPPU @ } 5 \text { ppm }\end{array}$ & 69.58 & 52.69 & 16.87 & 46.85 & 53.15 & 46.85 & 5.43 \\
\hline $\mathbf{T}_{4}+\mathrm{CPPU} @ 5$ ppm & 42.42 & 19.32 & 23.12 & 49.41 & 50.59 & 49.41 & 11.68 \\
\hline $\mathrm{T}_{5}+\mathrm{CPPU} @ 5$ ppm & 45.31 & 22.05 & 23.26 & 45.24 & 54.76 & 45.24 & 12.08 \\
\hline$C D(p \leq 0.05)$ & 2.84 & 10.77 & 1.1 & 0.73 & 0.88 & 0.73 & 0.82 \\
\hline
\end{tabular}




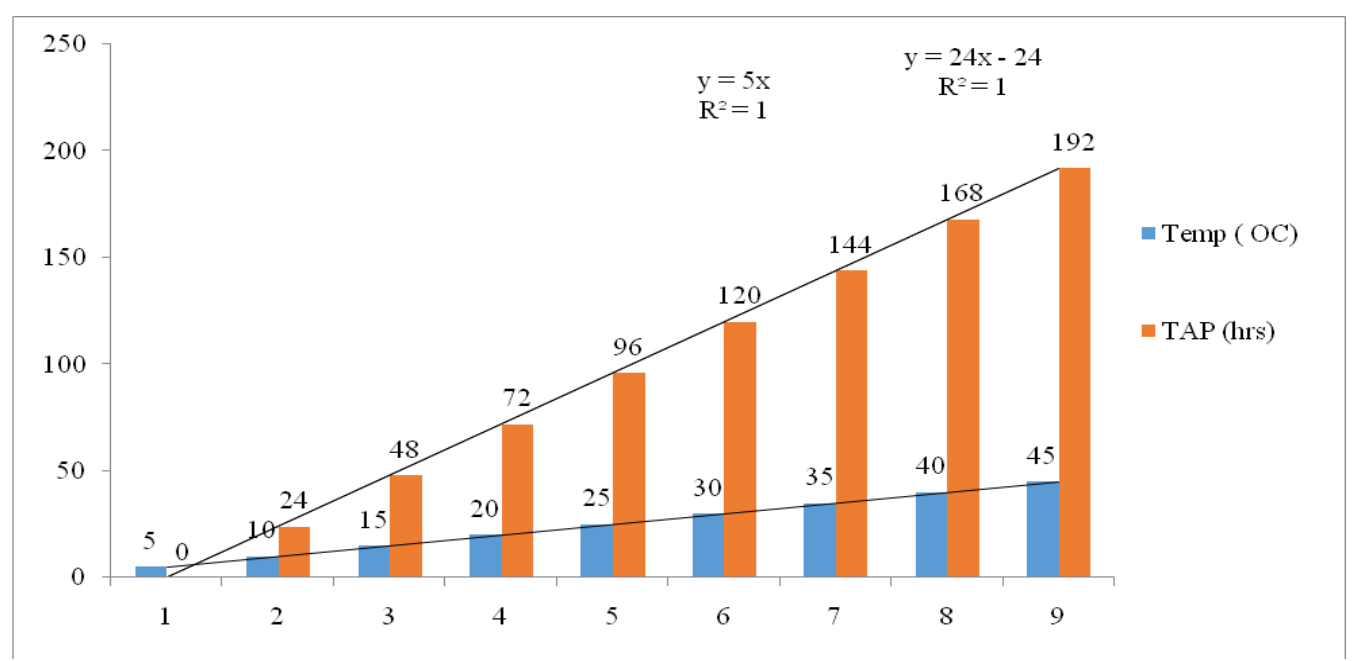

Fig.1 Hourly air temperature and the pollination period (First week of May): (TAP-Time after pollination in hours)

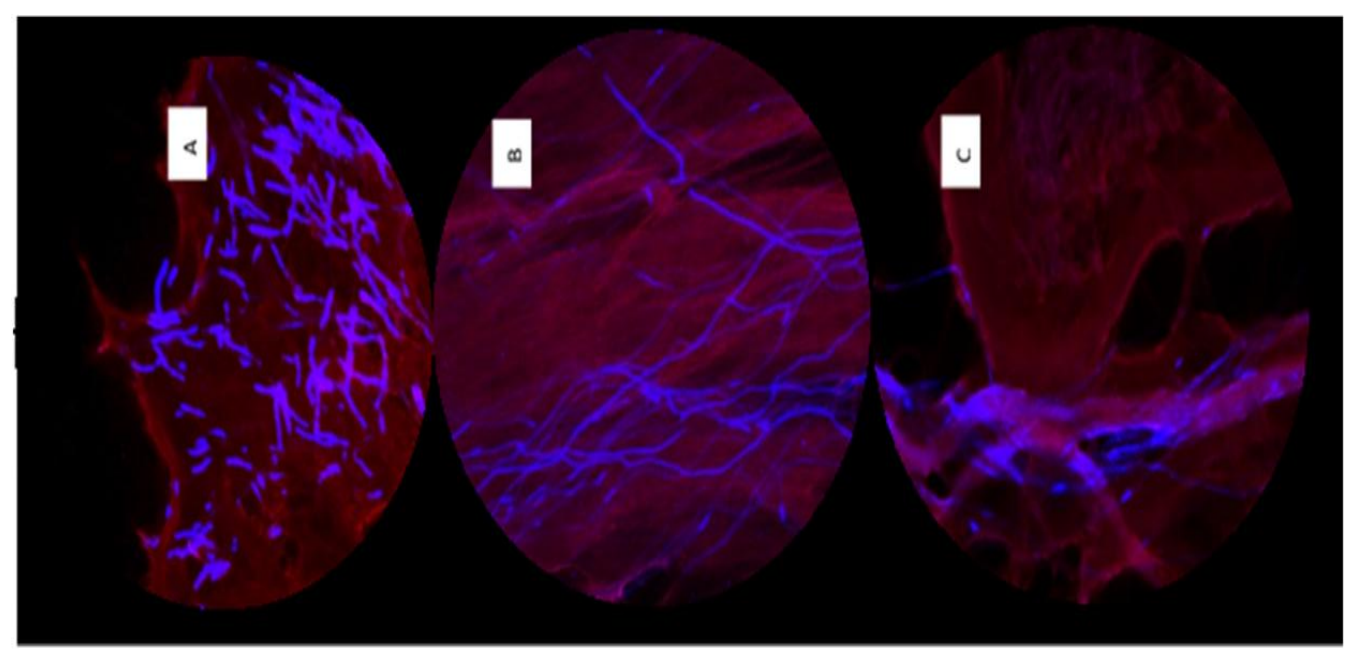

Fig.2 (A) Pollen tubes germinated on the stigmatic surface, (B) pollen tubes growth down the style, and $(\mathbf{C})$ pollen tubes that reached the base of the style of 'Fuji' flowers

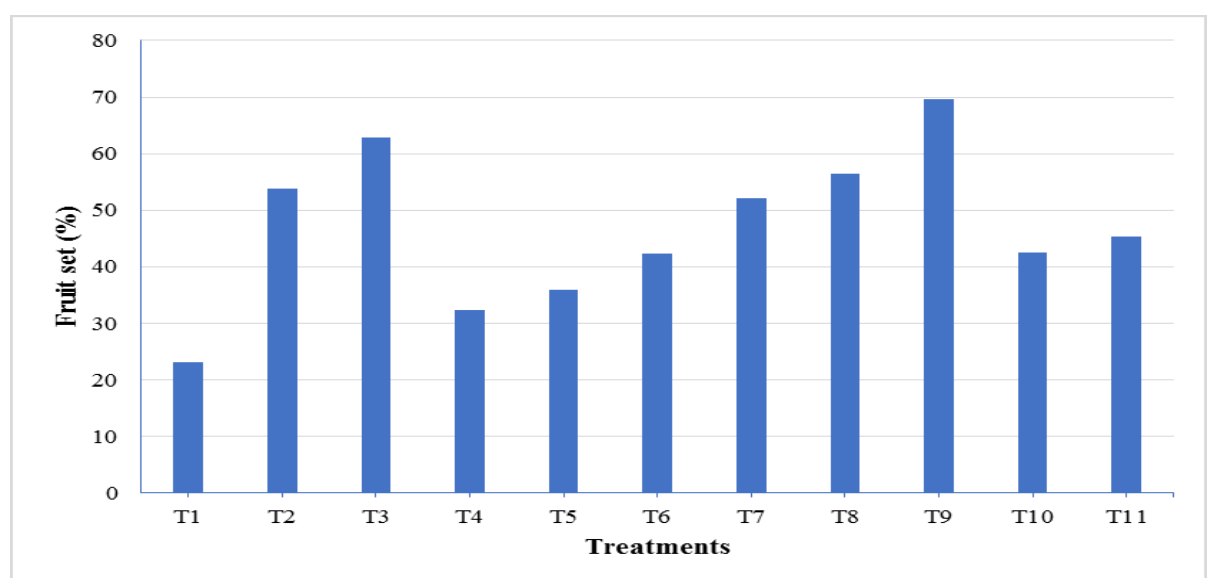

Fig.3 Impact of different phytohormones and nutrients alone or in combination on fruit set (\%) in Apple $c v$. Red Delicious (Wani et al., 2017) 
VARIOUS DEVELOPAENTAL STAGES OF $\mathbb{A P P L E}$ FRUIT

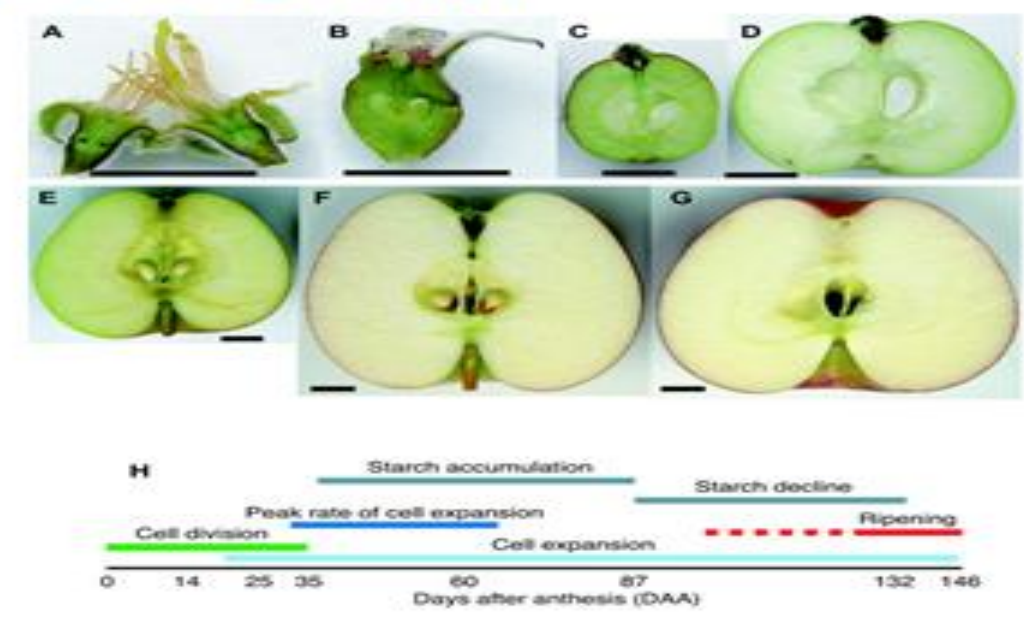

Fig.4 Various stages

SEASONAL GROMTH PATUERN OF AिPR區

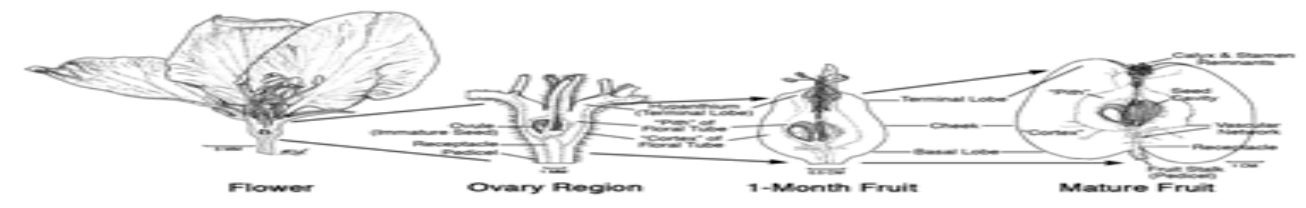

Diagram of apple flower and how it evolves into a fruit

Lakso and Goffinet, 2016

Fig.5 Seasonal growth pattern of apple

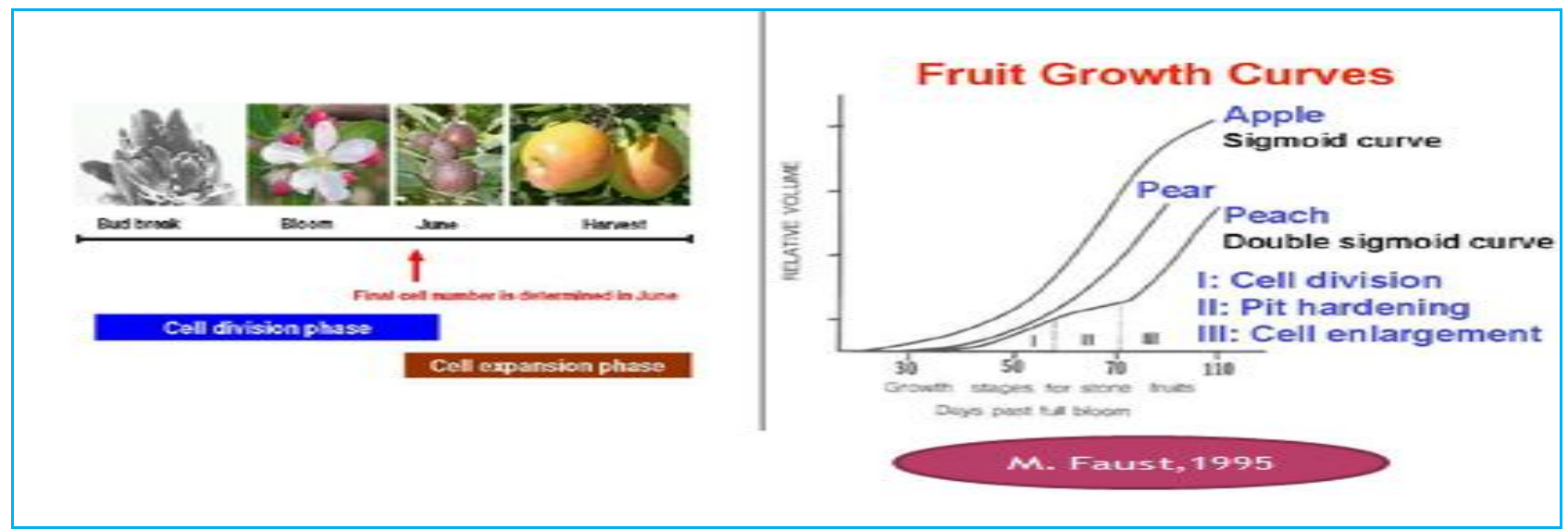

Fig.6 Cell division and expansion phase

Fig.7 Fruit growth curves 


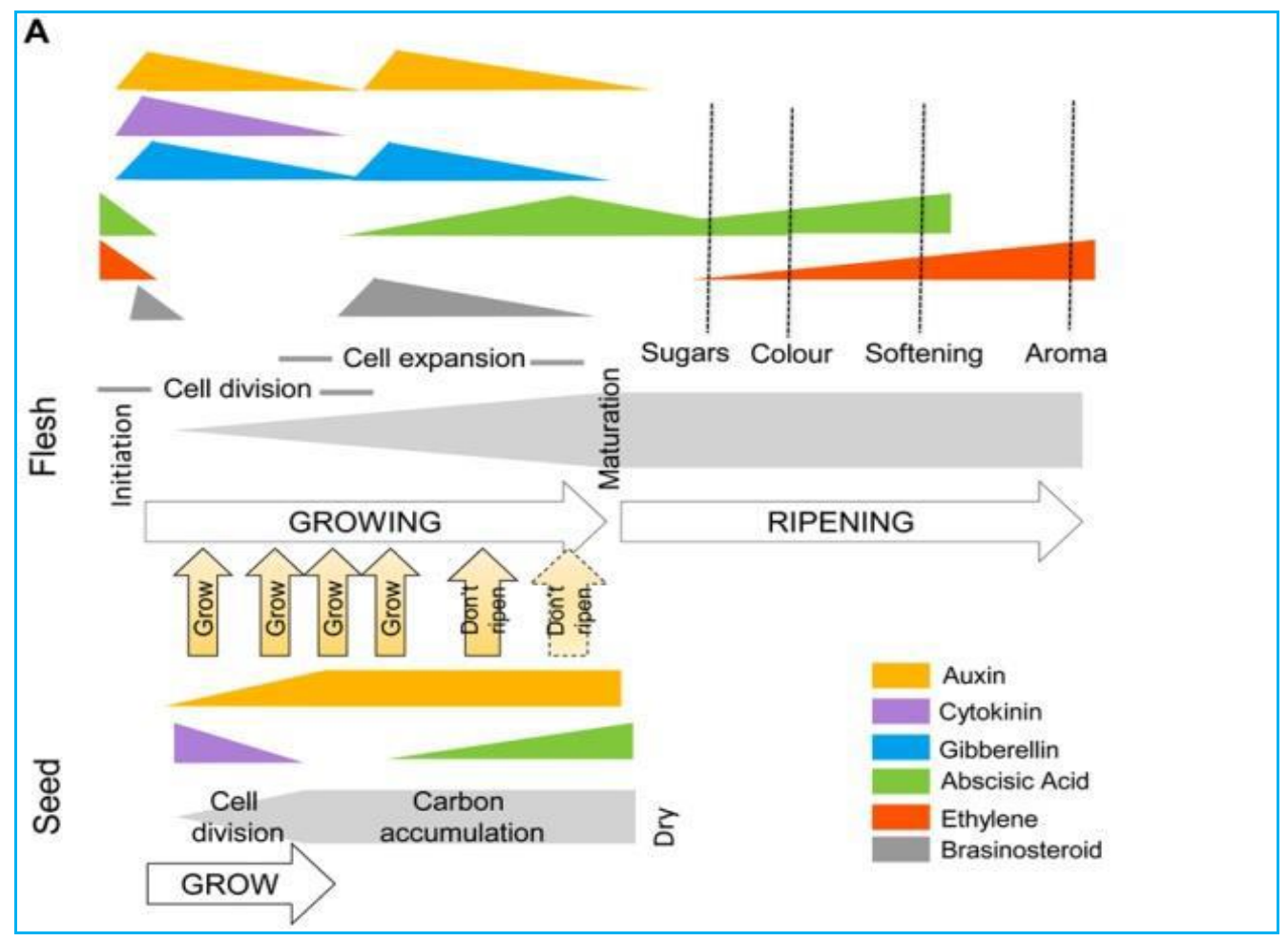

Fig.8 Hormonal changes occurring during fruit development (McAtetee et al., 2013)
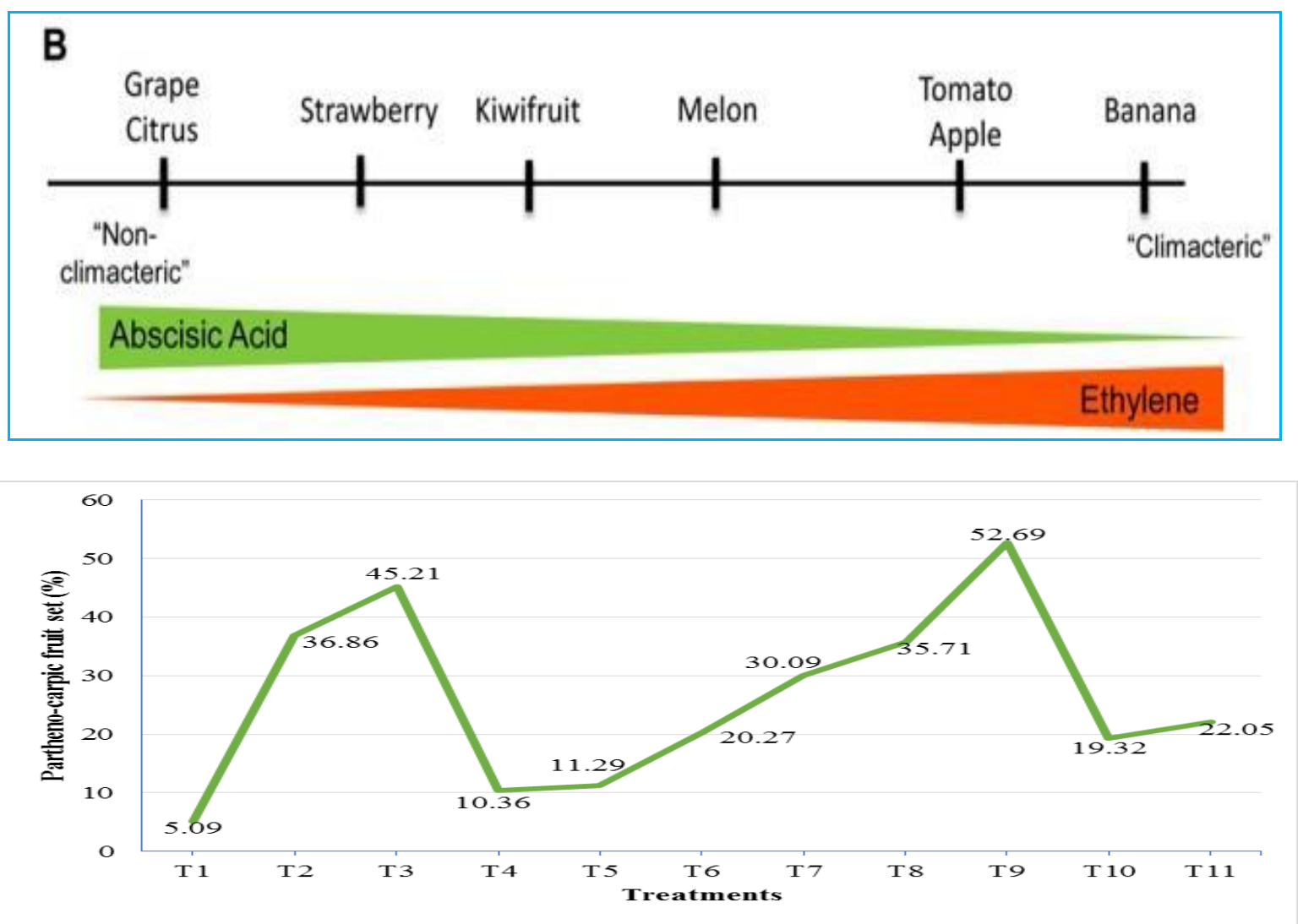

Fig.9 Influence of different phytohormones and nutrients alone or in combination on Parthenocarpic fruit set (\%) in Apple $c v$. Red Delicious 


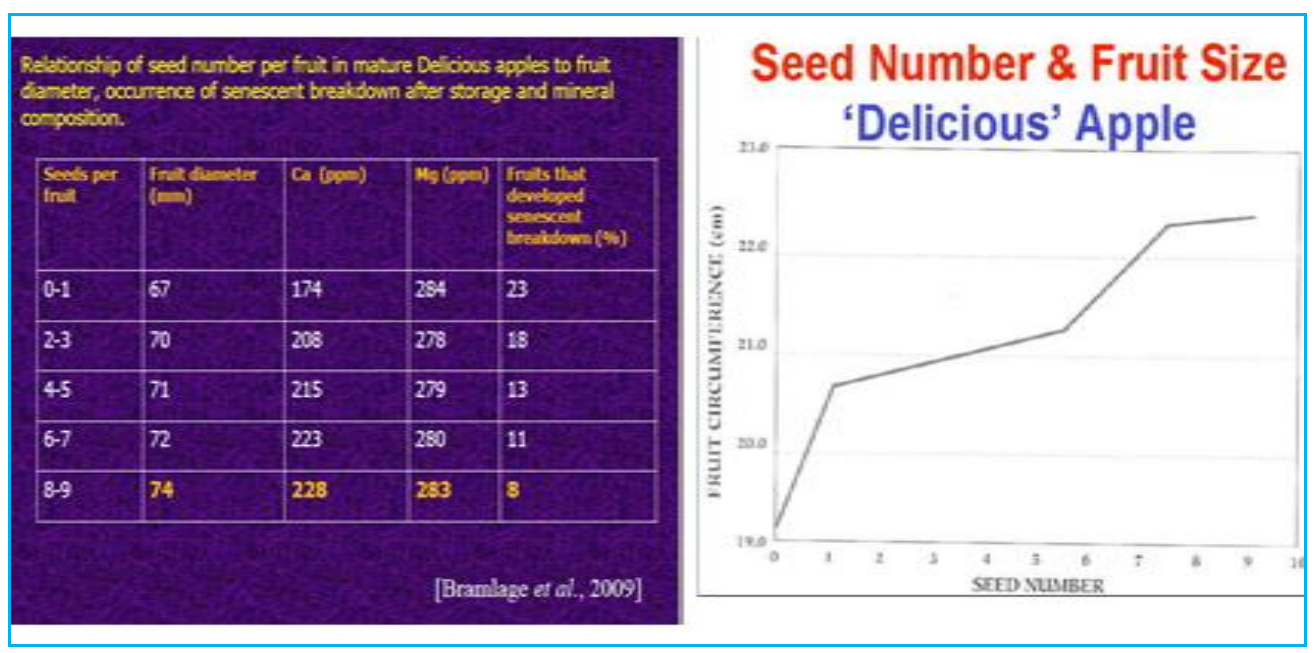

Fig.10

RELATLONSHIP BETAEEN SEED NUAQERR AND GROATH RATE OF CW. RED DELICUOUS

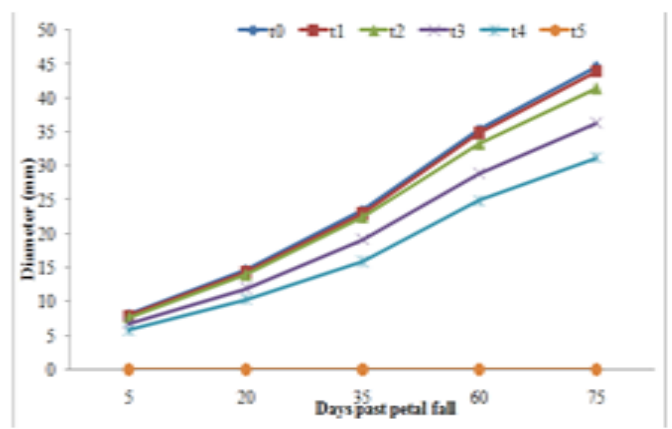

Eijaz et al, 2017

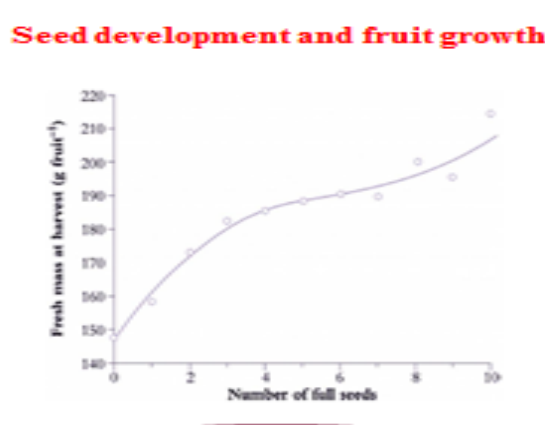

Broome et al., 2010

Fig.11 Relationship between seeds, calcium and Auxin (Luckwill, 1989)

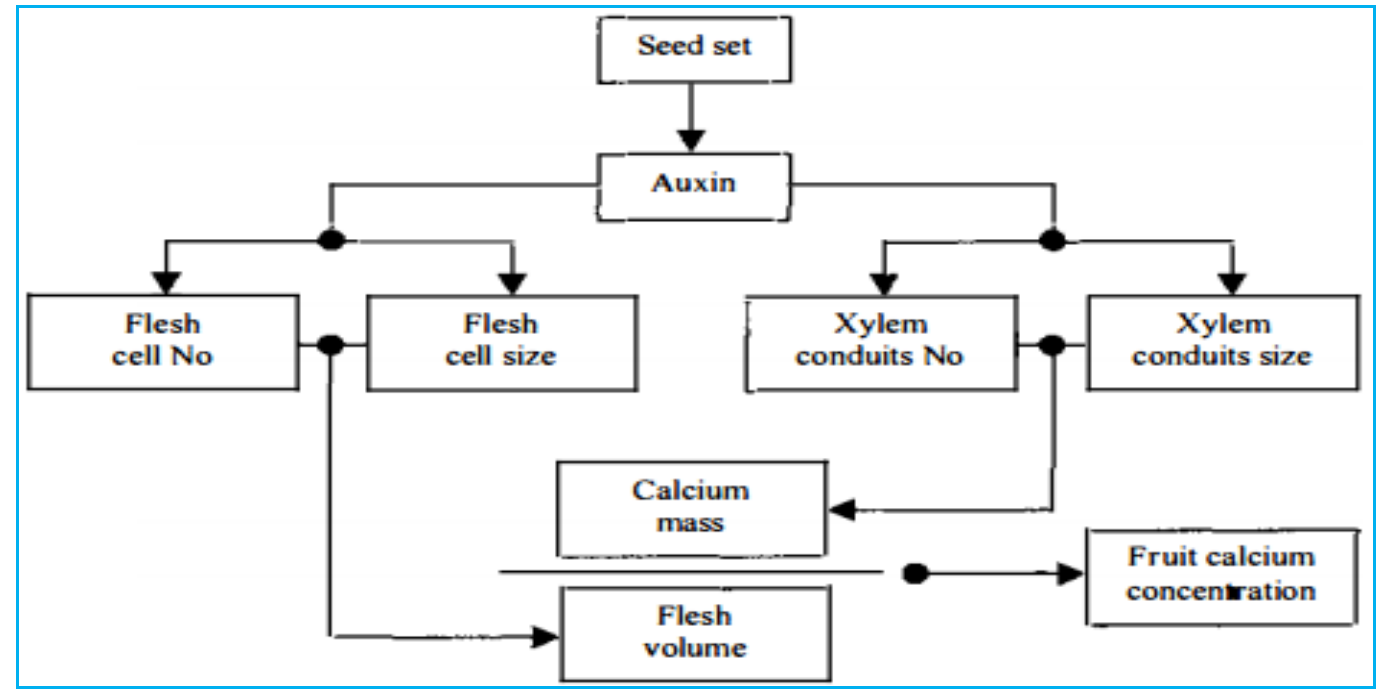

Fig.12 
Prang et al., (1998) revealed that the $\mathrm{GA}_{3}$ (250 or $500 \mathrm{ppm}$ ) sprayed at full bloom reduced the number of flowers in the following year of both Elstar and Golden Delicious apple cultivars. Moreover, $\mathrm{GA}_{3}$ (250 mg/liter) at full bloom caused an increase in diffusible IAA during the critical period of flower induction. Unrath and Whitworth (1999) studied that the application of $\mathrm{GA}_{3} @ 250$ and 500 ppm on "Red chief Delicious"/M.7 apple resulted in reduction in return bloom of 0.4 and 0.1 as compared to untreated control (7.8).

Byers et al., (1990) confirmed that $\mathrm{GA}_{3}$ reduced return bloom in peach when applied at full bloom. In nectarine, Garcia-Pallas et al., (2001) found that flowering was reduced in a linear relationship with concentration of $\mathrm{GA}_{3}(200 \mathrm{mg} / \mathrm{L}) . \mathrm{GA}_{3}$ has also been shown to reduce flowering of sweet cherry (Prunus avium L.) as compared to control. Dennis et al., (1970) demonstrated decreased levels of flowering in the pome fruit 'Bartlett' pear (Pyrus communis) with $20-100 \mathrm{mg} / \mathrm{L}$ of $\mathrm{GA}_{3}$ in following spring. In 'Kosui' Japanese pear (Pyrus pyrifolia Nakai), application of $\mathrm{GA}_{3}$ at $200 \mathrm{ppm}$ during flowering decreased flower bud formation, while August sprays of the same material increased flowering in coming spring (Ito et al., 2000).

The reduction in return bloom in the following spring can be due to the reason that gibberellins cause flower bud inhibition and there is more vegetative growth (Curry and Green, 1993). Also gibberellin delays plastichron i.e.initiation of vegetative bud to flower bud with the result critical node number does not reach at particular period due to which there occurs restriction of reserves, minerals and hence there occurs no flower bud formation. Also $\mathrm{GA}_{3}$ extends plastichron and bud never reaches the receptive stage, thereby indirectly inhibiting flowering (Zahoor and Dhillon, 2011). Bloom density is vital reproductive parameters which are directly related to fruit yield and productivity. Wojcik (1999) has reported that $\mathrm{B}$ application on pome and prune trees increased the density of flowers on shoot which led to the increased yield. While as, Usenik and Stampar (2002) have reported significant increase in number of blossom per branch from 162 (control) to 216 $(\mathrm{B}+\mathrm{Zn})$ in sweet cherry var. "Giorgia". Wojcik and Wojcik (2006) did not record any improvement in flower density in sweet cherry by foliar or soil B (boric acid) application during two years of studies.

Poor fruit set is due to poor pollination in orchards, is one of the factors limiting crop productivity. Pollination problems need attention in the early stages for good production and quality. The preferable solution to this problem is planting of appropriate ratio of pollinizer varieties, and honey bees for pollination. Under adverse climatic conditions that causes flower drop resulting poor fruit set which in turn decreases productivity .So use of PGRs particularly auxin, and/or gibberellin, and/or cytokinin $\left(\mathrm{GA}_{3}\right.$ and $\left.\mathrm{CPPU}\right)$, nutrients $(\mathrm{Ca}$, Boron, $\mathrm{K}$ and $\mathrm{N}$ ) alone or in combination promotes fruit set either by Parthenocarpic fruit set or increasing pollen viability and germination.

\section{References}

Abbott DL. The bourse shoot as a factor in the growth of apple fruits. Annals of applied Biology 1960; 48:434-438.

Aichner M, Stimpfl E. Seasonal pattern and interpretation of 60 mineral nutrient concentrations in apple trees. In: International Sympysium on Foliar Nutrition of Perennial Fruit Plants, Meran. ISHS, Brussels, Book of Abstracts. 2001: 89-99.

Annonymus, 2018. Progress Report, Department of Horticulture (Kashmir), Jammu and Kashmir.

Banday FA, Sharma MK. Present status of temperate fruits in Jammu and Kashmir; and strategies. In: Advances in temperate fruit 
production. Kalyani Publishers, New Delhi, 2010, 13-17p.

Banday SA. Effect of hand and chemical blossom thinning on yield and quality of apple (Malus domestica) cv. Red Delicious. M.Sc Theses. SKUAST-K, 2006.

Bangerth, F. and Schroder, M. 1994. Strong synergistic effects of gibberellins with the syntheticcytokinin N-(2-chloro-4-pyridyl)-Nphenylurea on parthenocarpic fruit set and some other fruit characteristics of apple. Plant Growth Regulators 15: 293-302.

Bhat, Z. A and Dillion, W. S.2011.Fruit tree physiology.Narendra publishing house Delhi. Pp93-94.

Bramlage WJ, Weis SA, Greene DW. Observations on the Relationships among Seed Number, Fruit Calcium, and senescent Breakdown in Apples. Hort Science. 2009; 25(3):351-353.

Broome, W., Damo, R.Prang.TandTrompt.T.2010. Effect of seed development on growthanddevelopment of apple fruit.Acta Horticulture3(4): 4-9

Byers, R.E., Carbaugh, H.D and Presley, N.C. 1990. The influence of bloom thinning and GA sprays on flower bud numbers and distribution in peach trees. Journal of HorticultureSciences 65:143-150.

Chao, T.C. and Lovatt, J.C. 2006. Effects of concentration and application time of $\mathrm{GA}_{3}$ and urea on yield, fruit size distribution and crop value of clementine mandarin in California. Acta Horticulturae 727: 227-234.

Cosgrove DJ. Growth of the plant cell wall. Nature Reviews Moecular Cell Biology. 2005; 6:850-8

Csukasi F, Osorio S, Gutierrez JR, Kitamura J, Giavalisco P, Nakajima M. Gibberellin biosynthesis and signalling during development of the strawberry receptacle. New Phytologist. 2011; 191:376-390

Curry, E.A. and Greene, D.W. 1993. CPPU influences fruit quality, fruit set, and return bloom andpreharvest drop of apples. Horticulture Science 28(2): 115-119.

Dennis. F.G., Edgerton. J.L and Parker.G.K .1970. Effects of gibberellin and Alar sprays upon fruit set, seed development, and flowering of 'Bartlett 'pear. HortScience 5(3):158-160.

Devoghalaere, F., Doucen, T., Guitton, B.,
Keeling, J., Payne, W. and Ling, T.J. 2002. A genomics approach to understanding the role of auxin in apple (Malus $\times$ domestica) fruit size control. BMC Plant Biology 12: 7 .

Dresselhaus T, Franklin TF. 2013. Male-female crosstalk during pollen germination, tube growth and guidance, and double fertilization. Indian Journal of Horticulture6(4):1018-1036 Verma, L .R and Jindal, K.K. 1985. Fruit crops pollination. Kalyani Publishers, 62-71p.

Dumas, C., Berger, F., Faure, J.E. and MatthysRochon, E. 1998. Gametes, fertilization and early embryogenesis in flowering plants. Advances Botany Research28: 231-261.

Ejaz.A.P, Rehman.M, Samiullah.S., Ali.T.M., Bhat.A.T., Rafiq.I and Hassan.G.2017.Effect of incomplete pollination on the physical quality attributes of Apple cv.Red Delicious Borkh.Current Journal of applied science and technology24(1) :1-6

El-Shazly SM, Eisa1 AM, Moảtamed AMH, Kotb HRM. Effect of Some Agro-Chemicals Preharvest Foliar Application on Yield and Fruit Quality of "Swelling" Peach Trees. Alex. J Agric. Res. 2013; 58(3)219- 229.

Faust.M.1995.Physiology of temperate-zone fruittrees. Wiley, New York.

Ganie, A. M., Farida, A., Bhat, M. A., Malik, A.R., Junaid, J.M., Abas, M., Arif, H.B. and Tauseef, A.B. 2013.Boron-a critical nutrient element for plant growth and productivity with reference to temperate fruits. Current Science 104:76-85.

Garcia-Pallas, I., Val. J and Blanco. A.2001. The inhibition of flower bud differentiation in Crimson Gold nectarine with $\mathrm{GA}_{3}$ as an alternative to hand thinning. Science Horticulture(Amsterdam)90:265-278.

Gillaspy, G., Ben-David, H. and Gruissem, W. 1993. Fruits: a developmental perspective. PlantCell5: 1439-1451.

Giovannoni. J.J, Lee. J.M., Chung. M.M and Fox. E. Molecular analysis of the developmental and hormonal systems regulating fruit ripening. Acta horticulturae. 2010; 884(884):41-50.

Goldway,M.,R.Stern,A.Zisovich,A.Raz.,G.Sapir, D.SchniederandR.Nyska.2012.Theselfincomt ability fertilization system in 
Rosaceae:Agricultural and genetic aspects Acta Hort.967:77

Greene, D.W. and Curry, E.A. 1989. Effect of CPPU on fruit set, fruit characteristics and preharvest drop of apples. Horticulture Science 24: 223

Guirguies, N.S., Attala, E.S. and Ali, M.M. 2003. Effect of sitofex (CPPU) on fruit quality of Le- Conte pear cultivar. Annals of Agricultural ScienceMoshtohor41(1): 271282.

Gupta, U.C. 1979. Boron nutrition of crops. Advances in Agronomy19: 157-209.Zatylnyl, A.M. and St-Pierre, R.G. 2006. Development of standard concentrations of foliar nutrients for Saskatoon. Journal of Plant Nutrition29: 195-207.

Hajam MA. Effect of gibberellic acid, Applin and calcium foliar sprays on chemo-metric attributes of apple (Malusx domestica Borkh.). M.Sc Thesis. SKUAST-K, 2017.

Hajam. M. A, G.I .Hassan, Tariq A. Bhat, I. A Bhat, A.M. Rather and E.A. Parray 2017.Understanding plant growth regulators, their interplay: For nursery establishment in fruits. International Journal of Chemical Studies5 (5):905-910.

Hamamura, Y., Nagahara, S. and Higashiyama, T. 2012. Double fertilization on the move. Curr. Opin. Plant Biology15: 70-77.

Hamamura, Y., Nagahara, S. and Higashiyama, T. 2012. Double fertilization on the move. Curr.

Harb .J.,Streif .J and Bangreth K.F. Aroma volatiles of apples as influenced by ripening and storage procedures. Acta Hort. 2008; 796:94-103.

Hossain, S. 2015. Development of nutritional quality and biochemical content of bilimbi fruit by using plant hormone and bark stress .Global Journal of Bio-Science and Biotechnology 4(4): 342-346.

Icka, P. and Damo, R. 2013. Effect of Promalin on fruit shape and quality of golden and Red Deliciouscultivars at the region of Korça. Annals "Valahia" University of Târgovişte4(8): 265-272.

Ito, A., Hayama, H and H. Yoshioka,H. 2000. Effects of plant growth regulators and their time of application on flower bud formation of Japanese pear 'Kosui. 'Journalof JapaneseSociety Horticulture Sciences.
69(5):529-535.

Jackson.J.E.2003.The biology of apples and pear Cambridge University Press, Cambridge, UK.

Jain. V.K. Fundamentals of Plant Physiology, S. Chand \& Company Ltd. 2013, 301-358.

Kadir, S.A. 2004. Fruit quality at harvest of "Jonathan" apple treated with foliarly-applied calciumchloride. Journal of Plant Nutrition27(11): 1991-2006.

Kano, Y. 2003.Effects of $\mathrm{GA}_{3}$ and CPPU treatments on cell size and types of sugars accumulated inJapanese pear fruits. Journal of Horticulture Sciences and Biotechnology74(3): 331-334

Khalil.R.J and Hirst.M.P.2017.Pollen tube growth and fruit set in apple.Hortscience 52(8):1054-1059

Kumar A. Feminization of androcious papaya leading to fruit set by ethereal and chlorflurenol Proc. $8^{\text {th }}$ Symposium Plant Bioregulators, Acta Hort. 1998; 463:251259.

Lasko AN, Goffinet MC. Apple fruit growth. New York Fruit Quarterly. 2013; 21(1):11-14.

Lee, S., Kim, W. and Han, T. 2009. Effect of postharvest foliar $\mathrm{B}$ and $\mathrm{Ca}$ applications on subsequent seasons pollen germination and pollen tube growth of pear (Pyrus pyrifolia).ScientiaHorticulturae 122: 77-82.

Luckwill LC, Weaver P, MacMillan J. Gibberllins, and other growth hormones in apple seeds. Journal of Horticulture Science. 1969; 44:413-424.

Luckwill LC. Studies of Fruit Development in Relation to Plant Harmones. IV: Acidic auxins and growth inhibitors in leaves and fruits of the apple. Journal of Horticultural Science. 1957 ; 32:18-33.

Luckwill LC. The Hormone Content of the Seed in Relation to Endosperm Development and Fruit Drop in the Apple, Journal of Horticultural Science. 1948; 24(1):32-44.

Maksymiuk, J., Grochowska J.M and D. Knzewinska.D .1986.Effect of successively applied four growth regulators on shoot elongation, flowering and fruiting of apple cu1tivar Fantazia. Fruit Science Reports. 13: 4, 149-160.

Mariotti L, Picciarelli P, Lombardi L, Ceccarelli N. 2011. Fruit- set and Early Fruit Growth in 
Tomato are Associated with Increases in IndoleaceticAcid, Cytokinin, and Bioactive Gibberellin Contents. Journal of Plant Growth Regulation30(4):405- 415.

Mariotti, L., Picciarelli, P., Lombardi, L. and Ceccarelli, N. 2011. Fruit-set and early fruitgrowthintomato are associated with increases in indoleacetic acid, cytokinin, and bioactive gibberellin contents. Journal of Plant Growth Regulators30: 405-415.

Marschner, H. 1995. Mineral nutrition of higher plants. $2^{\text {nd }}$ Edition. New York. Academic Press pp. 379-396

Matsuo S, Kikuchi K, Fukuda M, Honda I, Imanishi S. Roles and regulation of cytokinins in tomato fruit development. Journal Experimental Botany. 2012; 63:5569-5579.

Mc-Artney, S. and Wargo, J. 2008. Promalin (6$\left.\mathrm{BA}+\mathrm{GA}_{4+7}\right)$ increases cropping of apples after a freeze by promoting parthenocarpic fruit set. Journal of Japan Society Horticulture Science 77: 350-357.

McArtney, S.J. 1994.Exogenous gibberellin affects biennial bearing and the fruit shape of 'Braeburn' apple. New Zealand Journal of crop and Horticultural science. 22: 343-346.

McAtee.p, Karim. S., Robert,S and David.K.2013. The dynamic interplay between phytohormo nes is required for fruit development, maturation, and ripening. Plant Cell Biology 4(79): $1-7$

Musacchi, S. 2008. Impact of Promalin on parthenocarpic fruit set of pear. Journal of Agricultural Research Brazil pp. 20-24.

Niu, Q., Wang, T., Li, J., Yang, Q., Qian, M. and Teng, Y. 2014. Effect of exogenous application of $\mathrm{GA}_{4+7}$ and $\mathrm{N}$-(2-chloro-4pyridyl)-N-phenylurea on induced parthenocarpy and fruit quality in pyrus pyrifolia, Cuiguan, p. 341.

Opin. Plant Biology15: 70-77.

Osama. H.M., Amro. E., Salama. S.M and Bakeer, M.M. 2015. Effect of growth regulator, antioxidant and application date on fruiting and fruit quality of mango trees $c v$. Keitt.

IOSR Journal of Agriculture and Veterinary Science 8:87-95.

Pattison RJ, Catala C. Evaluating auxin distribution in tomato (Solanumlycopersicum) through an analysis of the PIN and AUX/LAX gene families. Plant Journal. 2012; 70:585-598.

Prang, L., Stephan, M., Schneider, G. and Bangeth, F.K. 1998. Gibberellin signals originating from apple fruit and their possible involvement in flower induction. Acta Horticulturae 463: 235-242.

Raghavan, V. 2003. Some reflections on double fertilization, from its discovery to the present. New Phytology159: 565-583.

Ramirez, H., Torres, J., Benavides, H.J. and Robledo, V. 2004. Fruit bud Initiation in Apple $C V$ Red Delicious Linked to Gibberellins and Cytokinins. Rev. Soc. Quím. Méx48: 7-10

Robbertse, P.J., Coetzer, L.A. and Bessinger, F. 1992. Boron: Uptake boron avocado leaves and influence on fruit production. Proceeding of 2nd World Avocado Congr.1: 173-178.

Sadamatsu, M., Keawladdagorn, V., Ohara, H., Ohkawa, K. and Matsui, H. 2004. Induction ofparthenocarpic fruit growth with endogenous gibberellins of loquat. Acta Horticultuare 653: 67-70.

Saure, M.C. 2005. Calcium translocation to fleshy fruits: Its mechanism and endogenous control.Scientia Horticulture 105: 65-89.

Shorrocks, V.M. 1997. The occurrence and correction of boron deficiency. Plant and Soil193: 121-148.

Srivastava A, Handa AK. Hormonal regulation of tomato fruit development: a molecular perspective. Journal of Plant Growth Regulation. 2005; 24:67-82.

Stampar, F., Hudian, M., Dolenc, K. and Usenik, V. 1999. Influence of foliar fertilization on yield and quality of apple (Malus $\times$ domesticaBorkh.). In: Improved crop quality by nutrient management Dordrecht. The Netherlands: Khrwer Academic Publishers pp.91-94.

Stamper, F., Sturm, K. and Usenik, V. 2000. Influence of foliar fertilization on yield, quantity and quality of apple (Malus $\times$ domesticaBorkh.). In: Improved crop quality by nutrient management (Eds. D. Anac and P. Martin-Prevel). Dordrecht, Kluwer Academic Publishers p. 91.

Trompt, J.1982. F1ower-bud formation in apples as affected by various gibberellins. Journal 
of Horticultural Science, 3: 277-282.

Tucker, D.P.H., Alva, A.K. and Wheaton, T.A. 1999. Nutrition of Florida Citrus Trees. University of Florida, SP p. 169.

Unrath, C.R. and Whitworth, J. 1999. Suppression of apple bloom with gibberellin sprays. Journal of Horticultural Science66: 155-157.

Usenik and Stampar 2002. Effect of foliar application of zinc plus B on sweet Cherry fruit set and yield. Acta Horticulturae594: 30-40.

Vivian-Smith, A. and Koltunow, A.M. 1999. Genetic analysis of growth regulator-induced parthenocarpy in Arabidopsis. Plant Physiology 121: 437-451.

Wally, A.S.M., H. Mokhtar and E.M. EI-Fakhany 1999. Effect of Biozyme and Gibberellic acid on fruitset, yield and fruit characters of "Costata" persimmon. Egypt Journal of Agricultural Research77(2): 805-815.

Wally, A.S.M., H. Mokhtar and E.M. EI-Fakhany 1999. Effect of Biozyme and Gibberellic acid onfruitset, yield and fruit characters of "Costata" persimmon. Egypt Journal of Agricultural Research77(2): 805-815.

Wang, Q.L., Lu, L.D., Wu, X.O. and Li, J.X. 2003. Boron influence pollen germination and pollen tube growth in Pica meyeri. Tree Physiology23: 345-351

Wani,W.A., G.I. Hassan, I.G., ShahidQayoom Dar,Q.S.,Baba,R., Dar,I.M., Amir.S., Bisati, A.I., Bhat.G.I and Hassan.Gh.2017. Influence of Different Phytohormones and Nutrientson Fruit set and Chemometric Attributes of Apple.Vegetos- An International Journal of Plant ResearchVegetos (Special) 2017:492-498

Wasfy, E.H. 1995. Growth regulators and flowering. Academic bookshop, Egypt pp. 560-580.

Watanabe, M., Segawa, H., Murakami, M., Sagawa, S. and Komori, S. 2008. Effects of plant growthregulators on fruit set and fruit shape of parthenocarpic apple fruits. Japan Society Horticulture Science 77: 350-357.

Westwood ,M.N, Batjer, L.P, and Billingsley HD. Cell size, cell number and fruit density of apples as related to fruit size, position in the cluster and thinning method. Journal of the

American Society for Horticulture Science. 1967; 120:802-807.

Wojcik, P. and Wojcik, M. 2006. Effect of B fertilization on sweet cherry tree yield and fruit quality. Journal of Plant Nutrition29: 1755-1766.

Wojcik, P., Mika, A. and Cieslinski, G. 1999. Effect of boron fertilization on the storage of apples (Malus $\times$ domesticaBorkh.). Acta Horticulturae485: 393-397.

Yahata, S., Miwa, M., Ohara, H., Ohkawa, K. and Matsui, H. 2006.Effect of application of gibberellins in combination with forchlorfenuron (CPPU) on induction of seedless fruitset and growth in Triploid Loquat. Acta Horticulturae 727: 263-268.

Yang, J., Zhang, J., Huang, Z., Wang, Z., Zhu, Q. and Liu, L. 2002. Correlation of cytokinin level inthe endosperms and roots with cell number and cell division activity during endosperm development in rice. Annals Botany90: 369-377.

Yang, J., Zhang, J., Huang, Z., Wang, Z., Zhu, Q. and Liu, L. 2002. Correlation of cytokinin levels in the endosperms and roots with cell number and cell division activity during endosperm development in rice. Annals Botany90: 369-377.

Yoder,K.,R.Yuan,L.Combs,R.Byers,J.McFerson and T.Schmidt.2009.Effects of temperature and the combinations of liquid lime sulfure and fish oil on germination ,pollen tube growth, and fruit setinapples.Hort-Science 44(5):1277-1283.

\section{How to cite this article:}

Hassan. G. I., Ab. W. Wani, S. Q. Dar, M. Younus Wani, J. A. Sofi, T. R. Baba, E. Parray and Rasool. A. 2020. Physiology of Fruit Set and Development in Apple under Temperate conditions: A Review. Int.J.Curr.Microbiol.App.Sci. 9(06): 618-638. doi: https://doi.org/10.20546/ijcmas.2020.906.080 